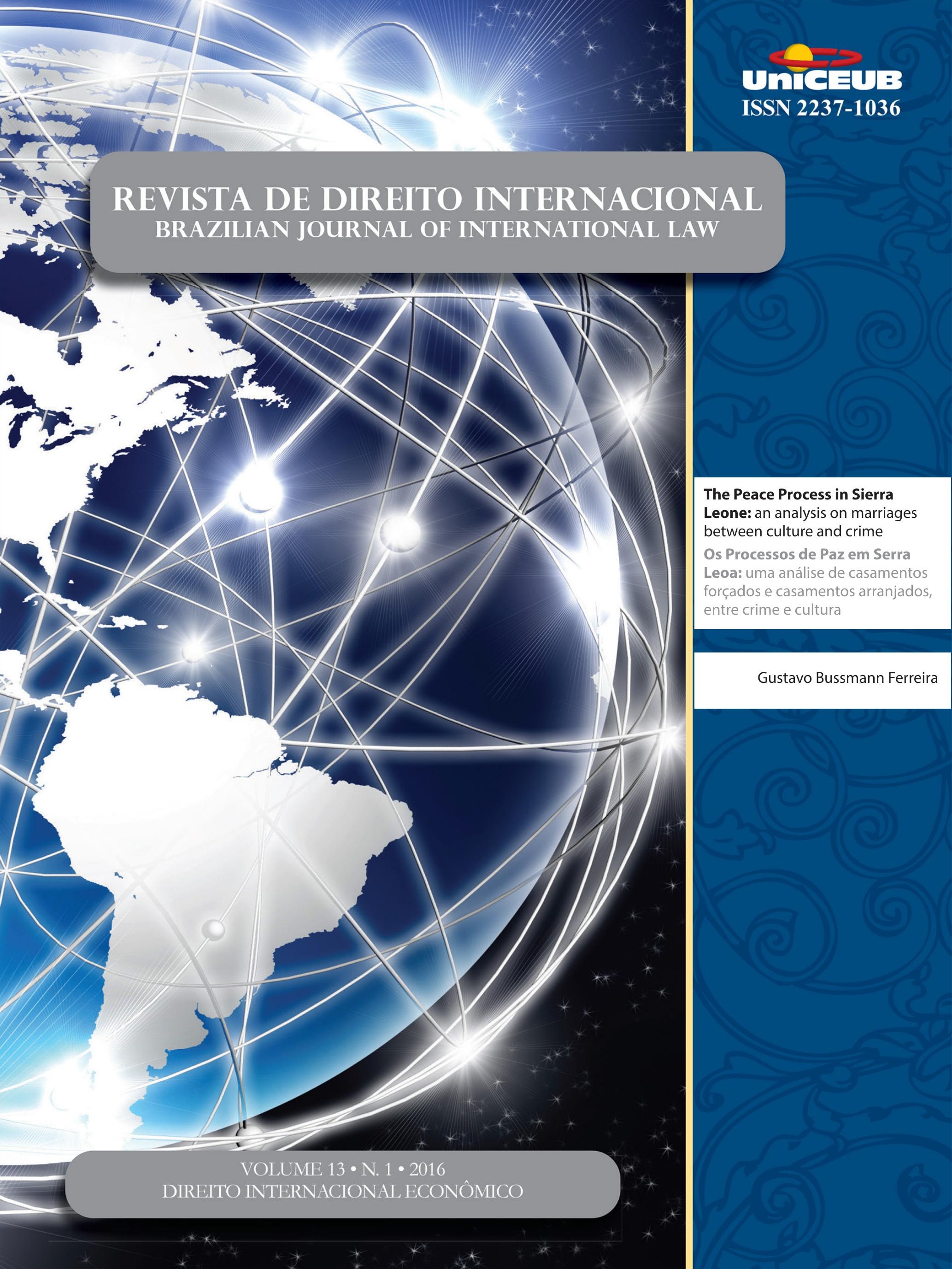




\section{Sumário}

Dossiê Temático: Direito Internacional Econômico.........................................................1

EDITORIAL:

Resultados da III Conferência Bienal da Red DEI ................................................. 3

Michelle Ratton Sanchez-Badin (em nome da Diretoria da Red DEI), Fabio Costa Morosini e Lucas da Silva Tasquetto (em nome dos organizadores da III Conferência da Red DEI)

Direito Internacional Econômico no Brasil: QUem Somos E o QUE faZemos? EvidênCIas EMPÍRICAS DE 1994 A 2014

Michelle Ratton Sanchez Badin, Fabio Costa Morosini e Inaê Siqueira de Oliveira

UM ESPAÇO PARA PENSAR EM ALTERNATIVAS? A ACADEMIA LATINO-AMERICANA DE DIREITO INTERNACIONAL ECONÔMICO FRENTE À ORDEM ECONÔMICA GLOBAL

Nicolás Marcelo Perrone

Grupo de alto Nível Brasil - Urugua (GAN): um Novo paradigma para a INTEgraÇão PRODUTIVA NO MERCOSUL

Alebe Linhares Mesquita e Vivian Daniele Rocha Gabriel

O COMÉRCIO de SERVIÇOS ENTRE Brasil E URUGUAI: LiberalizaÇÃo, DESAFIOS E PERSPECTIVAS DO SETOR DE TECNOLOGIA DA INFORMAÇÃO E COMUNICAÇÃO (TIC) E SOFTWARES

Vivian Daniele Rocha Gabriel e Alebe Linhares Mesquita

Core Labor Standards No Regime de PREFERÊNCIAS TARIFÁrias No MERCOSUL: A NeCESSIDADE DE HUMANIZAÇÃO DO COMÉRCIO INTERNACIONAL

Martinho Martins Botelho e Marco Antônio César Villatore

ACordo TRIMS: FleXibilizaÇão ou Não? Política de CONTEÚdo loCal, PROCESSO PROdUTIVO BÁSICO (PPB) E OS DESAFIOS PARA A INDÚSTRIA BRASILEIRA E A INTEGRAÇÃo LATINO-AMERICANA 100

Natália Figueiredo 
ESTUDIOS DE CASO DE RECHAZOS EN FRONTERA DE EXPORTACIONES ALIMENTARIAS LATINOAMERICANAS POR MOTIVOS RELACIONADOS CON MEDIDAS TÉCNICAS NO ARANCELARIAS.

Sofía Boza, Juan Rozas e Rodolfo Rivers

América do Sul em face dos tratados bilaterais de inVESTimento: RUMO aO RETORNo do EsTADO NA SOLUÇão DE CONTROvÉRSIAS? 133 Magdalena Bas

FutURo DE LOS SISTEMAS NACIONALES DE CIENCIA TECNOLOGÍA E INNOVACIÓN EN LA AGENDA ECONÓMICA DE AMÉRICA LATINA: DEFINIENDO CAMBIOS REGULATORIOS O PROTEGIENDO INVERSIONES 146

Rodrigo Corredor

EL PAPEL DE LAS INSTITUCIONES DE CONTROL FINANCIERO SOBRE LOS DERECHOS HUMANOS EN EL CONTEXTO LATINOAMERICANO 157 Jose Miguel Camacho Castro

CONVERGENCIA REgUlATORIA EN LA ALIANZA DEL PACÍFICO: UN CAPÍTULO INCONCLUSO 170 Rodrigo Polanco Lazo

O CONSTITUCIONALISMO E A COMUNITARIZAÇÃO NO DIREITO INTERNACIONAL: POSSIBILIDADES PARA O COMÉRCIO INTERNACIONAL?

Camilla Capucio

ESCASSEZ HÍDRICA E DIREITO INTERNACIONAL ECONÔMICO: O BRASIL COMO PROTAGONISTA NA TRANSFERÊNCIA DE ÁGUA PARA REGIÕES ÁRIDAS

Douglas de Castro

A Segurança energética como base para maior integração na América Do Sul: à espera DE UM TRATADO MULTILATERAL

Matheus Bassani

Outros Artigos. 246

As PRÁtICAS RESTRITIVAS DA CONCORRÊNCIA NO MERCADO DE CONTRATAÇÃo PÚBLICA EUROPEU .. 248 Alice Rocha da Silva e Ruth M. P. Santos 
Do TRANSNACIONAL PARA O NACIONAL: IOSCO, O MERCADO DE VALORES MOBILIÁRIOS BRASILEIRO E ACCOUNTABILITY

Salem Nasser, Nora Rachman e Viviane Muller Prado

MigRaÇÃo de TRABALHADORES INTELECTUAIS BRASILEIROS PARA O MERCADO INTERNACIONAL: IDENTIFICAÇÃO DE ATOS DE ALICIAMENTO DE EMPREGADOS E MECANISMOS LEGAIS PARA IMPEDIR A APROPRIAÇÃo TECNOLÓGICA E CONCORRÊNCIA DESLEAL ..........................................285 José Carlos Vaz e Dias e João Marcelo Sant'Anna da Costa

THE EASIER WAY TO HAVE "BETTER LAW"? THE MOST-SIGNIFICANT-RELATIONSHIP DOCTRINE AS THE FALLBACK CONFLICT-OF-LAW RULE IN THE PEOPLE'S REPUBLIC OF CHINA

Chi Chung

REFLEXOS JURÍDiCOS DA GOVERNANÇA GLOBAL SUBNACIONAL: A PARADIPLOMACIA E O DIREITO INTERNACIONAL: DESAFIO OU ACOMODAÇÃO 320

Valéria Cristina Farias e Fernando Rei

Matrizes Políticas da JUSTiÇA PENAL INTERNACIONAL. 341 Francisco Rezek

RESPONSABILIDAD INTERNACIONAL DEL ESTADO FRENTE A LUCHA CONTRA LA DISCRIMINACIÓN RACIAL Y ÉTNICA EN ESPAÑA. 348

Edilney Tomé da Mata e Eduardo Biacchi Gomes Correio

The Peace Process in Sierra Leone: an analysis on marriages between culture and CRIME

Gustavo Bussmann Ferreira

Funcionalização e expansão do Direito Penal: o Direito Penal negocial ...............376 Antonio Henrique Graciano Suxberger e Dermeval Farias Gomes Filho

Proteção Internacional do Consumidor e Cooperação Interjurisdicional .396 Héctor Valverde Santana e Sophia Martini Vial

The land rights of indigenous and traditional peoples in Brazil and Australia.... 418 Márcia Dieguez Leuzinger e Kylie Lyngard 
The reception of European ideas in Latin America: the issue of the German sources in Tobias Barreto, A Prominent nineteenth CENTURy BraZilian legal scholar........439 Arnaldo Sampaio de Moraes Godoy

Normas Editoriais ..................................................................................... 461 


\title{
The Peace Process in Sierra Leone: an analysis on marriages between culture and crime*
}

\author{
Os Processos de Paz em Serra Leoa: uma \\ análise de casamentos forçados e casamentos \\ arranjados, entre crime e cultura
}

Gustavo Bussmann Ferreira**

\begin{abstract}
In the context where universalism and cultural relativism shall coexist and there is a necessity to address societies by recognizing their multicultural features, it is of a great importance to examine how the perception of the world regarding a particular community may cause an impact on human rights. Victims of atrocities, who are without basic guarantees and transformed in some kind of homini sacri, must be recognized and protected to enable them to reconcile with their past and to restore themselves in post-conflict societies. The present work will analyze the Special Court for Sierra Leone which established limits to cultural practices such as forced marriages and arranged marriages - the first, a new kind of crime against humanity. Departing from these considerations, we aim to acknowledge how international law is important to promote multicultural respect alongside an affirmative jurisprudence of human rights, respecting them in its essence and presumed diversity. Moreover, how inclusiveness is a key issue to peace and how constitucionalism and democracy are essential matters to provide this recognition of humanity in each one.
\end{abstract}

Keywords: Multiculturalism. Forced marriage. Crimes against humanity. Peace process. Sierra Leone.

* Recebido em 03/04/2016

Aprovado em 30/05/2016

** Ph.D. Candidate in Human Rights and Democracy - Federal University of Paraná, Brazil, UFPR. Master of Laws in Human Rights and Democracy - Federal University of Paraná, Brazil, UFPR. Researcher of the Research Group in International Criminal Law for the ICC Moot Court Competition of the Groutius Centre for Human Rights, Leiden University, The Hague, for the Centro Universitário Curitiba, Unicuritiba, from 2010 to 2015. Trial Monitor for the American Bar Association, selected hard cases, since 2015. Attorney. Scholarship Student of the Brazilian Federal Agency for the Support and Evaluation of Graduate Education (CAPES/Proex). Email address: gus. bussmann@gmail.com.

\section{Resumo}

Em um mundo que considera a importância do universalismo e do particularismo coexistirem e a necessária percepção multicultural das sociedades, é salutar também que se analise em que medida a leitura de mundo de uma população pode infringir direitos humanos. Despidas de seus direitos básicos e transformados em homo sacer, as vítimas de atrocidades precisam de reconhecimento e proteção para que possam se reconciliar com o passado e se restabelecer nas sociedades pós-conflito. Nesse sentido, pretende-se analisar a perspectiva da Corte Especial para Serra Leoa, que estabelece limites para práticas de um costume ao diferenciar a prática de casamentos arranjados e o casamento forçado como uma nova vertente dos crimes contra a humanidade. A partir de critérios como o sofrimento da vítima e o conhecimento das circunstâncias pelo perpetrador, aponta-se em que medida a atuação do Direito Internacional é importante para promover uma jurisprudência afirmativa dos direitos humanos. 
Palavras-chave: Multiculturalismo. Casamento forçado. Crime contra a humanidade. Processos de paz. Serra Leoa.

\section{INTRODUCTION}

Taking into account new forms of human rights interpretations, which tend to harmonize universalism and cultural relativism, along with the emergence of an indispensable multicultural perception of societies, devoted to promote respectful interpretations of culture and traditions, the present work aims to comprehend to what extent a world view of a community may offend human rights.

In this context, victims of atrocities, who are stripped off most basic rights and transformed in homni sacri $^{1}$, must be recognized in their individualities and protected from 'traditions' in order to avoid impunity and permit social inclusion. Recognition and protection is done as a way to promote the reconciliation with their past, enabling the creation of a democratic future where culture, identities and human rights walk alongside.

The Peace Accords signed with the aim of putting an end to the conflicts in Sierra Leone, had also intentions of promoting social equality and peaceful coexistence of citizens - providing, in this way, the possibility of forgiveness after the most atrocious acts one can imagine. Societies who tolerate some sort of social groups/grouping in their very own assemblage promote dehumanization of people and transform atrocities in something usual and ordinary - what leads to more conflicts, in a community based on fear.

To address the boundaries between cultural-traditional practices and the criminal acts that may justify international interventions in one country, it will be analyzed the jurisprudence of the Special Court for Sierra Leone

1 Definition considered with regards to Giorgio Agamben works about citizens obliged to live in situations of extreme penuriousness, transformed in mere objects of the acts of the State. These lives that subsist with no dignity and protection in the Rule of Law, have lost also any value that they could have. In this sense, an homo sacer concept comprehension will permit the understanding of limits and boundaries about when characteristics are universal and when it should be comprehended as particular - with the possibility of inclusion and of living in the plenitude of human rights guarantees. AGAMBEN, Giorgio. Homo Sacer, o poder soberano e a vida nua. Belo Horizonte: Editora UFMG, 2010. p. 9. regarding forced and arranged marriages as well as the eventual punishment of those practices in the context of international human rights law. Forced marriages and its dimension of $\mathrm{attack}^{2}$ to victims of war (as other inhumane acts in the provisions of the Rome Statute of the International Criminal Court) and arranged marriages that happen worldwide as cultural practices and representations of identities show us that there is an urge to deal with diversity but also to respect human rights international standards.

This paper has the intent, therefore, to explicit how difficult is the harmonization of cultural aspects in the sense of respecting cultural values as arranged marriages in one hand and criminalizing inhumane practices as forced marriages on the other. The respect for identities and promotion of multicultural values will be the most valuable way to permit citizens to be respected regardless of their differences or of the conditions they share in essence (even when/if coming from different national identities). Furthermore, the case law of Sierra Leone will help us to seek a point of convergence where the specificities of every community are linked to each other and will, likewise, indicate new and intense forms of social inclusion after devastating conflicts - allowing citizens to participate in justice seeking procedures and to be recognized; to see their story told and to ensure the purpose of international law, which is to prevent impunity by assuring that crimes are properly investigated and prosecuted, as ascertained, for instance, by the preamble of the Rome Statute of the International Criminal Court.

Furhermore, Justice is an open concept and hard to be reduced to words, mostly if compared in the relation between eastern and western cultures. Because of this, the first step to the comprehension of the hybrid Courts in Sierra Leone and the democratic fight process against oppression and forced marriages is the notion of multiculturalism and the acceptance of the otherness as basis of Law and justice. In that ambiance, questions of violence and intolerance are so old as the exploration of people and diamonds in that community; although they share space and language, follow similar principles and traditions, differences always existed and the aim of

2 As the Rome Statute of the International Criminal Court in its Article 7 chapeau states about the requirement of a "widespread or systematic attack against a civil population" - which is, in our opinion, regarding to this case, more crucial towards determining an act against humanity than the classification of the 'unlawful acts'. 
getting richer and powerful became more intense along the years.

Practices as oppressive as forced marriages, therefore, may be revealed through "speech, writing or actions" 3 "; the ideologies that fomented those practices can be also recognized as the significant cause of the massacres - and that is why it becomes pretty clear why the post conflict politics had one special concern besides the actuation of the SCSL.

With necessary intentions of promoting equality, as well as the empowerment of women, it rests undoubted that it is necessary to avoid new forms of domination and to provide women a new place in the society - and this is very close to the prohibition of superiority speeches or hate practices in the country, transcending the past and looking forward to the future with healing and no demonization or dehumanization of the others.

\section{Sierra Leone on Marriages: an EMBLEMATIC CASE OF PHYSICAL AND MORAL AGGRESSIONS, BETWEEN CRIMES AND TRADITIONS}

In the pursuit of empowerment of justice and human rights, the Sierra Leonean case of post conflict recovery and process of peace is emblematic as the Special Court instituted there brought together elements of international criminal Law to the culture of that country and sought integration of people in a shared process of reconstruction. Considering that not every conduct may be accepted as mere characteristic of cultural expressions ${ }^{4}$, this process is important to reinforce ideals of liberty, dignity and the complementarity shared between countries and international organizations as indicatives that individualities and identities shall be protected without leaving aside international treaties and human rights norms 5 .

3 GERAGHTY, Mark. The Rwandan state's campaign against genocide ideology. Available at: <http://www.mmg.mpg.de/research/all-projects/the-rwandan-states-campaign-against-genocide-ideology/ $>$. Acessed: 08 July 2015.

4 ZIZEK, Slavoj. Eu não sou um daqueles esquerdistas loucos. Folha de São Paulo, São Paulo, 29 set. 2013. Disponível em: <http:/ / www1.folha.uol.com.br/fsp/ilustrissima /131366-quoteu-nao-souum-aquelesesquerdistas-loucosquot.shtml>. Acesso em: 10 out. 2013.

5 SCHARF, Michael P. Forward: Lessons from the Saddam Trial. Faculty Publications, Cleveland, n. 115, 2007. p. 1.
In this sense, it is indispensable to define the limits between traditions and criminal acts to identify when countries that tolerate some atrocious acts are likely to suffer international interventions in order to promote the end of impunity. Thus, the SCSL consider forced marriages as a crime against humanity taking into account the suffering of victims, knowledge of the circumstances by the perpetrator and gravity of consequences of the acts. Along with these acknowledgements regarding forced marriages, the jurisprudence will support the respect of arranged marriages traditions and expressions of the culture. Hence, a new form of interpretation arises to guide when international law may produce an affirmative jurisprudence on human rights and personal liberties ${ }^{6}$.

These considerations about the Sierra Leonean case have justifications, mostly, as the General Secretary of United Nations at the time of conflicts stated: "Sierra Leone represents one of the world's most successful cases of post-conflict recovery, peacekeeping and peace building. Here we have seen great strides towards peace, stability and long-term development". Furthermore, the civil war has taken 11 years and had acts of extreme violence that permits us to discuss the turning points when acts are no longer expressions of culture, traditions or free will, when it starts to cause offences to human dignity as clear affronts to human beings in their essence. Denying the possibility of having humanity, transforming people in naked livings, homni sacri, is a very specific point of concern today, mostly when these acts are disguised as culture. From 1991 until 2002 the Revolutionary United Front (RUF) and the Armed Forces Revolutionary Council (AFRC) in Sierra Leone have acted against the government and allies (Civil Defense Forces - CDF), leaving civil and combatants victims of a war defined by sexual violence, mutilation, abduction, rapes and forced marriages ${ }^{8}$, and this is the social framework that base our thoughts on the borderline existent between crime and culture.

6 SCSL. Promotor vs. Alex TambaBrima. Case N. SCSL-2004-16-A. Avaiable at: <http://www.rscsl.org/Documents/Decisions/ AFRC/Appeal/675/SCSL-04-16-A-675.pdf >. Accessed: 15 July 2014. p. 471.

7 MOON, Ban Ki. Transcript of the Secretary-General's remarks at Joint Press Conference with President of Sierra Leone, 2014. Avaiable at: $<$ http://www.un.org/sg/offthecuff/index.asp?nid=3337>. Accessed in: 24 Oct. 2014.

8 HUMAN RIGHTS WATCH. Bringing Justice: the Special Court for Sierra Leone. Available at: <https://www.hrw.org/report/2004/09/08/bringing-justice-special-court-sierra-leone/accomplishments-shortcomings-and>. Access in: 24 Oct. 2014. 
The trial of atrocities that took place in that country, as recognized in Human Rights Watch Reports, is essential to bring justice to victims, punish perpetrators and establish bases to the construction of the Rule of Law in post conflict societies'. Once recognized an incapacity of domestic courts to handle trials in Sierra Leone due to corruption, political manipulations and the low number of judges and courts, the head of state Tejan Kabbah has solicited United Nations to help with the creation of an hybrid court, domestic and international, to judge and analyze the crimes happened during $\operatorname{war}^{10}$ : the Special Court for Sierra Leone, set in The Hague, Netherlands ${ }^{11}$.

But when it comes to the present analysis, besides the convictions of Charles Taylor and the several crimes detected in that time and place, the first and foremost distinction that must be done is in relation of types/ modalities of marriages, as we can see: (i) marriage is a term utilized in a broad way to comprehend the union

9 HUMAN RIGHTS WATCH. Bringing Justice: the Special Court for Sierra Leone. Available at: <https://www.hrw.org/report/2004/09/08/bringing-justice-special-court-sierra-leone/accomplishments-shortcomings-and >. Access in: 24 Oct. 2014.

10 HUMAN RIGHTS WATCH. Bringing Justice: the Special Court for Sierra Leone. Available at: < https://www.hrw.org/report/2004/09/08/bringing-justice-special-court-sierra-leone/accomplishments-shortcomings-and >. Access in: 24 Oct. 2014.

11 About these hybrid courts that manage national Law and costumes as well as international Law, it is important to reinforce that their main intention is to remember the historical and social circumstances where the crimes happened while judging and making justice possible. Considering that an external intervention might bring up several questions about legitimacy of trials to citizens involved in conflicts in remote and isolated areas and that local courts would face lots of challenges to judge crimes with so great magnitude, the shared complementarity arises as an effective conjunction of efforts between states and the international community in order to pursuit peace. Domestic courts led to international patterns and conditions, therefore, are efforts of bring effectiveness to justice and respect to international standards of due process of law, as well as financial resources that would not be available to trials in local courts (3). The main focus, hence, is to promote identification of the population with justice and allow them to 'look to the future with the clearness of the facts happened in the past', ensured that impunity was affronted and the Rule of Law would be every day plural and more inclusive. (1) (HUMAN RIGHTS WATCH. Bringing Justice: the Special Court for Sierra Leone. Available at: <https://www.hrw.org/ report/2004/09/08/bringing-justice-special-court-sierra-leone/ accomplishments-shortcomings-and >. Access in: 24 oct. 2014). (2) (UNITED NATIONS. Security Council. Repertoire of the Practice of the Security Council, 2004. Avaiable at: <http://www.un.org/en/sc/ repertoire/2004-2007/Chapter\%208/Thematic/04-07_8_role\%20 of $\% 20$ civil $\% 20$ society $\% 20$ in $\% 20$ post-conflict $\% 20$ peace-building. pdf>. Accessed: 10 Oct. 2014). (3) SCHARF, Michael P. Forward: Lessons from the Saddam Trial. Faculty Publications, Cleveland, n. 115, 2007. p. 7). between two people, in civil, religious or common sense - known by both of people that are engaged, their relatives and the community where they are inserted; (ii) forced marriage is a concept used to define unions where there is no consent of one or both of the parts including succession of spouses, fiancé(e)s kidnapping, compensation of crimes and offering of people (mostly young girls and teenagers) as a payment of debits ${ }^{12}$; (iii) arranged marriages are constituted by cultural practices when there is consent from both parts in being submitted to the tradition where parents define the people to whom their brood will be united - and it is valid to highlight that, in this case, religious and identity matters may and probably will import on the decisions, which are not likely to happen when it comes to forced marriages ${ }^{13}$.

Forced marriages, therefore, as we consider the jurisprudence of SCSL, must be criminalized even if not brought as one of the examples of sexual crimes on the Rome Statute of the International Criminal Court. In its article 07(1)(g), "Rape, sexual slavery, enforced prostitution, forced pregnancy, enforced sterilization, or any other form of sexual violence of comparable gravity ${ }^{14}$ " are conducts that specifically must be analyzed by the court. However, even not being reduced to terms in this codification of norms, women from all over the world were contemplated with hope since this conduct was understood as a crime against humanity in accordance to the article $07(1)(\mathrm{k})^{1516}$.

Apart of the sexual crimes (in which the role of the International Criminal Tribunal for the former Yugoslavia must not be forgotten ${ }^{17}$, mostly when its jurisprudence defines the atrocious act of submitting someone to domestic activities and sexual intercourses as a

12 HUMAN RIGHTS WATCH. I've never experienced happiness. Available at: <http://www.hrw.org/reports/2014/03/06/ive-never-experienced-happiness>. Accessed: 24 Oct. 2014.

13 BLACK, Lisa. Arranged - not forced - marriages a good match in many cultures. Chicago Tribune, Chicago, 27 jul. 2011. Available at: <http://articles.chicagotribune.com/2011-07-27/news/ct-x0727-arranged-marriages-20110727_1_marriages-family-traditionsstephanie-coontz>. Access in: 27 Oct. 2014.

14 ROME Statute of the International Criminal Court, 2002.

15 Other inhumane acts of a similar character intentionally causing great suffering, or serious injury to body or to mental or physical health. ROME Statute of the International Criminal Court, 2002.

16 CLARK, James M. Forced Marriage: The Evolution of a New International Criminal Norm. Aberdeen Student Law Review, Aberdeen, v. 3, p. 4-27, 2012. p. 3.

17 ICTY. 25 may 1993, art. 5(c);(g). 
crime $^{18}$ ), the Special Court for Sierra Leone considered forced marriage a crime due to the gravity of a conduct that imposes great suffering to victims in a psychological manner ${ }^{19}$ : not only the sexual characteristic of the acts were considered, but also the inhumane character of them in the whole context. As the jurisprudence on the former Yugoslavia international tribunal consider sexual crimes in the perspective of the property sense of the perpetrator ${ }^{20}$, forced marriage crimes have, besides the abovementioned aspect, the psychological terror imposed to the victims that suffer violence as intellectual manipulations, domestic obligations and non consensual sex and pregnancy ${ }^{21}$.

Therefore, victims of forced marriage are obliged to have responsibilities related to children care, domestic economy and sexual intercourse with their own perpetrators, showing also a necessary affection. Victims were violently obliged to suffer rapes, pregnancies, and stigmatization even when free from their captors - not to forget, when it comes to these situations, the health issues $^{22}$ that come together with these atrocities. What is left to these women, the so-called 'bush wives', in the end, if we remember all of the activities they are coerced to, is the label of wife; in every other perspective, they were slaves or prisoners. Regardless of this label of wife, there is no bond of affection between the spouses, another reason why it is not a valid and real marriage taking into account article 16 of the Universal Declaration of Human: "Marriage shall be entered into only with the free and full consent of the intending spouses".

Emotional and psychological traumas caused to the victims must be considered, also, as from the stated by the report of the United Nations High Commis-

18 ICTY. Prosecutor vs. Kunarac et al. Case no IT-96-23T \& IT96-23/1-T, 2001. Avaiable at: <http://www.icty.org/x/cases/kunarac/tjug/en/kun-tj010222e.pdf>. p. 742.

19 SCSL. Prosecutor vs. Alex Tamba Brima. Case no SCSL-2004-16-A. 03.mar.2008, p.854.

20 ICTY. Prosecutor vs. Kunarac et al. Case $\mathrm{n}^{\circ}$ IT-96-23T \& IT96-23/1-T, 2001. Avaiable at: <http://www.icty.org/x/cases/kunarac/tjug/en/kun-tj010222e.pdf>. p. 539.

21 Corte Especial para Serra Leoa. Promotor vs. Alex TambaBrima. Caso no SCSL-2004-16-A. Julgamento de 03 mar. 2008, p. 61, parágrafo 189.

22 For Instance: "Rape sometimes led to women bleeding to death or suffering from tears in the genital area. Cohen points out that fistula, however, was more often caused by women giving birth in the bush without medical attention than by rape itself". In: WOMEN UNDER SIEGE. Sierra Leone. Available at: < http://www.womenundersiegeproject.org/conflicts/profile/sierra-leone>. Accessed: 20 Sept. 2014. sioner for Human Rights as caused by physical force, legal compulsion, economic coercion, intimidation and psychological manipulation $^{23}$ and in situations where there is no free acceptance and explicit consent ${ }^{24}$. As noted by Myriam Denov: "Rebels abducted a woman, isolated her, repeatedly gang raped her, and finally 'liberated' her via 'marriage' to a particular commander. Despite the violence of the final stage, abductees often described the commander who took them as saving their lives". The atrocities were brought to a very great level, when some women "felt 'lucky' to be forced into sexual enslavement with one man, rather than 'used' by many different men each day" 25 .

Likewise, it is important to highlight that victims of forced marriage in Sierra Leone had the stigmatization of being together with the rebellion militiamen, reason why they were object also of denial from their relatives and of marginalization that came from their pairs ${ }^{26}$. The word 'spouse', as well, demonstrates the control exercised by the 'husbands' over the women, once they were not only properties (as in crimes of sexual slavery), but people united in marital association, which there in Sierra Leone meant a necessity of obedience and respect ${ }^{27}$.

Stripped of any basis of autonomy and with a need to respect and obey their husbands, the victims were inducted to believe that their spouses had, even, right over their lives (and right to take it away). Consequently, without the protection of their families and with the possibility of being killed or left anytime, the injuries suffered and tamed transformed those women in mere objects of the pity of their husbands in the context of war (and even after it had been declared over) ${ }^{28}$.

23 UNITED NATIONS. Human Rights Council. Thematic study on the issue of violence against women and girls and disability. New York: UN, 2012.

24 UNITED NATIONS. Human Rights Council. Thematic study on the issue of violence against women and girls and disability. New York: UN, 2012.

25 WOMEN UNDER SIEGE. Sierra Leone. Available at: < http:// www.womenundersiegeproject.org/conflicts/profile/sierra-leone>. Accessed: 20 Sept. 2014.

26 JALLOH, Charles Chernor. The Sierra Leone Special Court and Its Legacy: the impact for Africa and International Criminal Law. New York: Cambridge University Press, 2014. p. 737.

27 SCSL. Promotor vs. Alex TambaBrima. Case N. SCSL-2004-16-A. Avaiable at: <http://www.rscsl.org/Documents/Decisions/ AFRC/Appeal/675/SCSL-04-16-A-675.pdf >. Accessed: 15 July 2014. p. 63.

28 JALLOH, Charles Chernor. The Sierra Leone Special Court and Its Legacy: the impact for Africa and International Criminal Law. New York: Cambridge University Press, 2014. p. 737. 
The protection of those victims by the international criminal law and the consideration of these acts as a crime against humanity are, therefore, huge steps in direction to the protection of women in their freewill and in the exercise of their dignity. Consider forced marriage as an inhumane act, as we analyse the Rome Statute in the article $07(1)(\mathrm{k})$, is to recognize the residual character of this provision and to protect these victims regarding their inherent dignity. The foundations of this protection and for the prohibition of other inhumane acts were stated by the Charter of the International Military Tribunal of Nuremberg in its article 06(c) and in the International Military Tribunal for the Far East Charter [art. 05(c)], in the International Criminal Tribunal for the Former Yugoslavia [art. 05 (i)] and in the Inter-

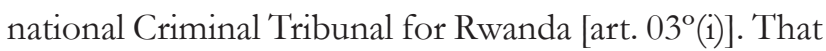
being stated, it was fair enough to the SCSL to recognize this crime since the non punishment of perpetrators would be an offence not only to the victims and their memories, but to the humanity as a whole ${ }^{29}$ - in a way that the protection of citizens and humankind is also based in jus cogens $s^{30}$ norms.

Besides the importance of this jurisprudence to the whole world, there was a preoccupation to these victims to be reintegrated to the society and to have their emotional stability restored (mainly with regards to the crimes committed against young girls). There were, hence, treaties involving UNICEF and local companies to promote popular reconciliation and democratic ideals ${ }^{31}$ - which were lastly fomented with the Lomé Peace Accord in 1999 in a try to effectively represent the ideals and points of view of the affected women. National Consultative Conferences and Women's organizations took place in Freetown bias to make women voices not only heard, but respected.

The main preoccupation with the victims of violations happened also by the "urgent necessity of a particular type of assistance to satisfy their present necessi-

29 SCSL. Promotor vs. Alex TambaBrima. Case N. SCSL-2004-16-A. Avaiable at: <http://www.rscsl.org/Documents/Decisions/ AFRC/Appeal/675/SCSL-04-16-A-675.pdf >. Accessed: 15 July 2014. p. 59.

30 As the Vienna Conventions on the Law of Treaties sustain in the article 53, reinforcing the importance of the principles of these norms. Therefore, fighting slavery and crimes against humanity when it comes to 'inbumane acts' are jus cogens norms, so, the prohibition of the commission of such harmful acts should be interpreted as mandatory for all States.

31 SINGER, Peter. Crianças em armas. Colares: Pedra da Lua, 2009. p. 213. ties, even if this would be useful only to put them in the same category of another victims ${ }^{32}$ " such the gravity of their condition was. Rehabilitation and re-inclusion are guidelines to be achieved by tribunals, mostly when it comes to crimes as the abovementioned forced marriages. Therefore, the identified lack of consent in the practice as well as the cultural perspective in the arranged marriages ${ }^{33}$, considering particularism and the value of protecting countries in their roots and traditions, was some of the greatest achievements of the Sierra Leonean court while bringing women to the front row of the reconstruction process; moreover these processes were extremely valuable to the recognition that marginalization and exclusion may be one of the fundamentals of war and that without freedom and inclusiveness, there is no way to find peace.

\section{Exclusion as a War Reason and an Obstacle to Peace}

Remembering that the war was not only one punctual sad moment in the history of the country is important when it comes to the analysis of its causes. Once the society was marked by inequality and exclusion of some social groups, it must be highlighted that these characteristics existed long before the war was initiated. Social and legal exclusion, thus, are crucial points that make possible to understand social and political atrocities in societies, both in the light of politics and global value ideals, taking into account that such these themes are of great relevance as we remember international criminal law and jus cogens norms.

Therefore, having marginalization and exclusion spread in the whole country and social groups that did not participate of the economic and political processes, the conflict was certainly not an isolated fact, but a consequence of deeper problems ${ }^{34}$. Also, we must be heedful that politics that deny humanity and make some people deprived of dignity and recognition are based

32 TRUTH AND RECONCILIATION COMISSION. Witness to Truth. v. 2. p. 197.

33 JALLOH, Charles Chernor. The Sierra Leone Special Court and Its Legacy: the impact for Africa and International Criminal Law. New York: Cambridge University Press, 2014. p. 202.

34 BARNES, Catherine; POLZER, Tara. The Sierra Leone peace process: learning from the past to address current challenges. Conciliation Resources, London, Sept. 2000. 
in the construction of some ideals, normally by State representatives. The exclusion of people, in addition, helps the constitution of some kind of hegemony once it is necessary to maintain some hierarchy of the dominant classes and the dehumanization of some others.

Thus, to this analysis, it is necessary to consider Antonio Gramisci works, to whom the supremacy of a group is noticeable in two ways, as domain and as in the promotion of intellectual and moral directions ${ }^{35}$. A social group when exercising its domain with the intent to destroy or submit (even with armed force) its 'enemies' - or people that do not fit in some ideals of standards of acceptance or recognition - intend to direct the way of living of the other groups and guarantee its positions in society ${ }^{36}$. As dully noted by victims of the war, "the government was not motivated to seek peace until the war threatened Freetown ${ }^{37}$ ", when the hegemonies were already threatened and the dominated groups were by the time insurgent. In this case, it must be clear that only on establishing rules and promoting political relations that promote recognition and plurality, something becomes possible: protecting citizens and promoting human rights is an unalienable responsibility of each State and this cannot coexist with ideologies of exclusion.

It is valuable, in this sense, to present which meaning of ideology should be taken into account for this analysis. The way a society works is constituted by images, languages and signs adopted by its social groups and this is an important place to start to understand how politics of oppression arises ${ }^{38}$. But is also important to analyze when and how these ideas begin and how the fundaments of this oppression relates to discourses and

35 GRAMSCI, Antônio. Risorgimento: notas sobre a Itália. Tradução Luiz Sérgio Henriques. Rio de Janeiro: Civilização Brasileira, 2002. p. 62-63.

36 Notions of hegemony and domination, by now, will be taken from the perspective of Ernesto Laclau and Chantal Mouffe, once they have considered plurality as a precondition of the human existence; well, no hegemonic logic could comprehend the totality of a society and this understanding is important as recognizing oneself in others - and this is the most important thing to value all forms of life and the real effectiveness of human rights. In: LACLAU, Ernesto; MOUFFE, Chantal. Hegemonía y estrategia socialista: Hacia una radicalición de la democracia. 2. ed. Buenos Aires: Fondo de Cultura Económica de Argentina, 2004. p. 186.

37 BARNES, Catherine; POLZER, Tara. The Sierra Leone peace process: learning from the past to address current challenges. Conciliation Resources, London, Sept. 2000.

38 HALL, Stuart. The problem of ideology: Marxism without guarantees. Journal of Communication Inquiry, Iowa, v. 10, n. 2, June 1986. p. 31. its conversion in common sense ${ }^{39}$, something that comes from an interior perspective and is converted in an exterior discourse - and institutionalizes hegemony and the maintenance of some sort of social status quo that intend homogeneous societies and the exclusion of those considered 'different'.

About this intention of bringing spaces homogenous inside the society, what can be perceived is that it is extremely related to the use of violence and with the denial of the alterity and humanity of some targeted groups, as we see in Sierra Leone. This denial, likewise, has the aim of domination of those groups and is of great concern, because denies also plurality, diversity and the possibility of some people to be recognized as a member of a community ${ }^{40}$. Thus, the importance of this acknowledgement is because the hegemony of a State and the denial of alterity had been used as means of maintenance of terror states and of destruction of citizens also in military dictatorships in Latin America and in conflicts in the Ex-Iugoslavia, for instance.

Therefore, the main goal of the accountability measures taken in Sierra Leone would have to address, to avoid a new war to begin, that its root causes as "public frustration at corruption, weak governing structures, limited public services and high unemployment, especially among the youth, in a context of deep and widespread poverty and poor economic prospects ${ }^{41}$ ". Women empowerment and protagonism in post conflict actions, in this sense, was a crucial element in peacemaking, once they were the most victimized category in that war - and also, the group that could represent the need of diversity and recognition of everyone's humanity in Sierra Leone. A huge example of their leadership and of their walk towards a new position in the society, therefore, was the National Consultative Conferences (Bintuani I and II) and the street manifests that spread into Freetown in 1995.

39 LACLAU, Ernesto; MOUFFE, Chantal. Hegemonia y estrategia socialista: Hacia una radicalición de la democracia. 2. ed. Buenos Aires: Fondo de Cultura Económica de Argentina, 2004. p. 171.

40 LAFER, Celso. A Reconstrução dos Direitos Humanos: a contribuição de Hannah Arendt. São Paulo: Companhia das Letras, 2003. p. 34.

41 DIVISION FOR THE ADVANCEMENT OF WOMEN. Expert group meeting. In: PEACE AGREEMENTS AS A MEANS FOR PROMOTING GENDER EQUALITY AND ENSURING PARTICIPATION OF WOMEN: A FRAMEWORK OF MODEL PROVISIONS, 2003, Ottawa. Aidé-Memoire. Otawa: DAW, 2003. Available at: <http://www.un.org/womenwatch/daw/egm/ peace $2003 />$. 
Hence, it must not be forgotten that "after thirty years of undemocratic regimes and warfare, there is a need to rebuild the social and moral framework of the country. This process will need great commitment from all Sierra Leoneans, not the external imposition of structures and agreements ${ }^{42}$ ". Another important point regarding the need of inclusion and recognition of women's rights, is that denials are not only related to hate speeches and in explicit attacks ${ }^{43}$. It is present when there is dehumanization of individuals and when ignoring them is a part of an ideology of repression ${ }^{44}$. The lack of recognition, therefore, results in demonization or invisibility in social and political life ${ }^{45}$.

Regardless of the representation of the victims' issue, which is always a dilemma of great concern, it must be taken into account that alongside the process of their inclusion ${ }^{46}$, the spirit of the international protection of human rights must be step-by-step constructed in a society, by "formal peace negotiations by political leaders", and by "informal activities, usually orchestrated by heterogeneous groups of voluntary grassroots organizations that seek to draw attention to particular issues during the transition period and thereby influence the formal process ${ }^{47}$ ".

Constitutions must be implemented and interpreted, thus, without any mention to exclusion and possibility of denying any person because of their characteristics. Considering patterns of hegemony, ideologies and dehumanization of some citizens, there is a huge risk to

42 BARNES, Catherine; POLZER, Tara. The Sierra Leone peace process: learning from the past to address current challenges. Conciliation Resources, London, Sept. 2000.

43 BARNES, Catherine; POLZER, Tara. The Sierra Leone peace process: learning from the past to address current challenges. Conciliation Resources, London, Sept. 2000.

44 SCARRY, Elaine. The Difficulty of Imagining Other Persons. In: HESSE, Carla; POST, Robert. Human rights in political transitions: gettysburg to Bosnia. New York: Zone Books, 1999. p. 282.

45 SCARRY, Elaine. The Difficulty of Imagining Other Persons. In: HESSE, Carla; POST, Robert. Human rights in political transitions: gettysburg to Bosnia. New York: Zone Books, 1999 p. 288.

46 BARNES, Catherine; POLZER, Tara. The Sierra Leone peace process: learning from the past to address current challenges. Conciliation Resources, London, Sept. 2000.

47 DIVISION FOR THE ADVANCEMENT OF WOMEN. Expert group meeting. In: PEACE AGREEMENTS AS A MEANS FOR PROMOTING GENDER EQUALITY AND ENSURING PARTICIPATION OF WOMEN: A FRAMEWORK OF MODEL PROVISIONS. 2003, Ottawa. Aidé-Memoire. Otawa: DAW, 2003. Available at: <http://www.un.org/womenwatch/daw/egm/ peace $2003 />$. the future of politics, democracies and solidarity ${ }^{48}$; but the new forms of interpretation and the history told by those Tribunals and to those victims gives us some fresh air to continue this journey.

From the considerations about the construction of the human rights theory as universal on, up to the confirmation that this model does not find consistent grounds, an important thing to be taken into account is how particular notions of rights and the relativity of concepts are important in order to establish material justice to citizens in a globalized and cosmopolitan world. Likewise, contributions to multiculturalism show us that, if taken to extremes (i.e., without the intersection of cultures and the consideration of forced marriages as culture), the world is perceived as a homogeneous matter, somehow by disregarding the importance of diversity and plurality.

From a different multiculturalist perspective, though, declarations of human rights have an universal foundation as a rule, considering that, a priori, every human being pursue recognition in the same way; similarly, the Universal Declaration of Human Rights treats such these individuals as if they all shared similar social and economic assumptions, in a unilateral worldview. However, one has to consider that there are several other conditions, besides economic and social ones, that should be duly considered to allow certain cultures to be in the process of discussing treaties and effectiveness on human rights, since a homogeneity of thoughts would, then, be nothing but totalizing; and its consequences would be harmful to countries, cultures and individuals (constrained in their freedom and dignity). The universality of human rights, therefore, must not be understood in its epistemic value, but in the right of every person to be recognized for their rights with the sole limitation of not violating the rights of others.

This way, the Sierra Leonean case is significant to investigate the differences of multiculturalism and global identifications that citizens share in essence, even when/if coming from different national identities. It denotes a point of convergence where the specificities are linked to each other and how they lead us to universality - not the contrary, and then the hybrid model of justice do not mean new forms of colonization, but the respect of what people share in essence: humanity.

48 LIMA, Abili Lázaro de Castro, 2006. 
Human plurality and diversity, therefore, lead us to the path that the protection of human rights will occur by giving effectiveness to the ideals of constitutionalism and democracy - and the democracy that is intended is not "liberal in its traditional conceptions, but in some new perspectives of democracy, radical and plural, because only in democracies it will be a possibility of non-totalitarism ${ }^{49}$. The realization of an individual bound to the realization of the others, as stated by Francesco D'Agostino, happens in the sense that "men have rights because they are one with another, because the existence of one requires the existence of the other, because in one identity, the singular is attached to the plural; the affirmation of one happens with the recognition of the other ${ }^{50}$.

\section{Final Considerations}

Considering the great impact of the above mentioned crimes and the harm caused to victims and their families, we reiterate the importance of inclusive processes and recognition of humanity in each and every citizen, regardless of their sex or social context. Hence, interpretations that shall be made on law, culture and atrocities must be focused in the respect of human rights and in the responsibility of countries and their representatives to promote equality and trials of everyone that institute politics of denial of humanity.

As Sierra Leonean government assumed the compromise of effectively implement gender inclusion politics and focus on the promotion of human rights protection in its democratic society ${ }^{51}$, it is important to remember that the trials of the perpetrators had an important role in the journey towards peace. As perceived by Priscila Haynes: "When there are legitimate, credible, and fair charges against such pivotal individuals, and es-

49 KOZICKI, Katya. A política na perspectiva da filosofia da diferença. In: OLIVEIRA, Manfredo. et. al. (Org.). Filosofia política contemporânea. Petrópolis: Vozes, 2003. p. 141-160.

50 D’Agostino, 1996 apud BARreto, Maira de Paula. Os direitos humanos e a liberdade cultural. Revista Antropos, v. 1, ano 1, nov. 2007.

51 DIVISION FOR THE ADVANCEMENT OF WOMEN. Expert group meeting. In: PEACE AGREEMENTS AS A MEANS FOR PROMOTING GENDER EQUALITY AND ENSURING PARTICIPATION OF WOMEN: A FRAMEWORK OF MODEL PROVISIONS. 2003, Ottawa. Aidé-Memoire. Otawa: DAW, 2003. Available at: <http://www.un.org/womenwatch/daw/egm/ peace $2003 />$. pecially if they are believed to be involved in inciting violence, an appropriate process of arrest and prosecution can have a direct and positive effect on the peace process $^{52}$ ". Furthermore, the emblematic role of the tribunals includes the message that impunity must not be tolerated and that human diversity is a key role in the constitution of societies. Without citizens feeling free to assume their identities and their free will, no possibility will exist in the sense of freedom in a global world.

Irrespective of the construction of identities and their expression in some community, as well as morals and comprehensions of each citizen that may vary, it is the responsibility of the States to give materiality to human rights and dignity, to make effective what treaties and charts tend to protect. The constitution of these, in this sense, will encompass matters as rights to liberty, equality, democracy and sovereignty, which will have by consequence right to be a member of a global republic ${ }^{53}$. The analyzed case law, also, is important to history as give value to the intentions provided by the human rights treaties that were strengthened in the last century $y^{54}$ and respect particularities of women in a war that was greatly harmful to them. It was a great achievement of the SCSL, consequently, that women participation in the reconciliation procedures were not only important to the post-conflict reconstruction, but to their own global and inclusive benefit ${ }^{55}$ (to their visibility and to the possibility of healing their vulnerabilities and invisibilities).

Considering the hazards caused by war and remembering the initial purpose of international criminal law, mindful that the most serious crimes that affects the international community as a whole must not go unpunished and that justice to victims must be provided, there is an universal need to countries promote trials and manage the pursuit of justice, specifically when acts are offensive to human rights in its essence and

52 HAYNER, Priscila. Negotiating peace in Sierra Leone: confronting the justice challenge. Report, Geneva, Dec. 2007.

53 KERSTING, Wolfgang. Universalismo e direitos humanos. Porto Alegre: EDIPUCRS, 2003. p. 95.

54 KERSTING, Wolfgang. Universalismo e direitos humanos. Porto Alegre: EDIPUCRS, 2003. p. 771-797.

55 DIVISION FOR THE ADVANCEMENT OF WOMEN. Expert group meeting. In: PEACE AGREEMENTS AS A MEANS FOR PROMOTING GENDER EQUALITY AND ENSURING PARTICIPATION OF WOMEN: A FRAMEWORK OF MODEL PROVISIONS. 2003, Ottawa. Aidé-Memoire. Otawa: DAW, 2003. Available at: <http://www.un.org/womenwatch/daw/egm/ peace $2003 />$. 
presumed diversity. States and its constitutions must provide a normative text that aims to promote basic rights and symbolic politics ${ }^{56}$, not means to the execution of atrocities - and this interpretation comes from the new forms of transterritorial relations that brought up a necessity to constitutionalism to go across state boundaries ${ }^{57}$ - respecting historical constructions and cultural conceptions of every community.

Furthermore, the access to justice and the pursuit of an inclusive society encompass the existence of strong confidence in domestic law as well as in international courts. Specifically in Sierra Leone, clear and accurate information regarding the obligations assumed in treaties and stablished by jus cogens norms had a prominent role in the peace process - with clarity intended ways to avoid a new war to break out ${ }^{58}$. Moreover, the signing of a peace accord is surely no guarantee of a new era, inclusive and justice-based. There is a daily challenge of accountability that must be highlighted by State representatives, responsible by the promotion of the Rule of Law and by the assurance that there is no more space of misinterpretation of international values and of reproduction of hegemonies that exclude some groups of citizens.

The Supreme Court of Sierra Leone's decisions had helped us to identify, therefore, how universalism and relativism relate to each other and how we can manage traditions in a global community; and, by considering multiculturalism, when some practices do not have justification in tradition and must, therefore, be understood as a crime. The local analysis and its relations to international criminal law, therefore, leads us to find the individual not as something abstract, but as a community member and holder of identity, provenance and heritage. Thus, the intent, considering their local, national and transtational public spheres, is to examine human rights in their global character, as well as in their local legitimacy. Thanks to its interpretation that guarantees new and intense forms of social inclusion, the international human rights treaties in its global acting may be justified in the action of international courts. This way, this jurisprudence permits one to investigate the differences of multiculturalism and global identifications

56 KERSTING, Wolfgang. Universalismo e direitos humanos. Porto Alegre: EDIPUCRS, 2003. p. 771-797.

57 NEVES, Marcelo. Transconstitucionalismo. São Paulo: Martins Fontes, 2009. p. 120.

58 HAYNER, Priscila. Negotiating peace in Sierra Leone: confronting the justice challenge. Report, Geneva, Dec. 2007. that citizens share in essence, even when/if coming from different national identities; to seek a point of convergence where the specificities are linked to each other and how they lead us to universality - not the contrary, and this relation to international courts.

As human rights and international law play a prominent role in the fight against impunity and the protection of the victims of the above mentioned crimes, besides the construction of denial of citizenship and human condition politics and its role in mass atrocities, the importance of the Sierra Leonean Tribunal and decisions in order to provide peace and justice in post-conflict societies are an important analysis. Social and legal exclusion, thus, are crucial studies to make possible to understand social and political changes in transitional societies, both in the light of politics and global value changes, taking into account that such these themes are not only current, but also of relevance. With these considerations done, this work tried to provide forms of identifying victims of human rights violations that arise from offensive methods of repression and denial of alterity; also, the necessity of strong democracies to avoid new politics similar to that.

The strengthen of constitutional states and judiciary systems to implement basic rights must be, hence, attached to the valorization of local identities and rights of minorities so as to avoid gender oppression and sex violations as a way to promote war. The engagement of States to permit inclusion will give power to excluded groups and victims, as the women in Sierra Leone, enabling, consequently, the creation of public spaces to articulate and question their own identities (free to do this, not subjected to hegemonic powers ${ }^{59}$. In this context, bearing in mind that the harm of the victims are normally physical and psychological, and with the view of ensuring meaningful victims' participation in the trials, as well as effectiveness of the proceedings, it is no longer possible to accept passively recorded testimonies from public hearings absent from the victims engagement, lack of substantive investigations and any other form of initiative that does not reflect the pursuit of bringing justice to the affected population.

Equality and inclusion, therefore, lead us to the path that the protection of human rights will occur only by

59 ZIZEK, Slavoj. Bem-vindo ao deserto do real: cinco ensaios sobre o 11 de Setembro e datas relacionadas. Tradução Paulo Cezar Castanheira. São Paulo: Boitempo, 2003. 
giving effectiveness to the ideals of constitutionalism and democracy - and democracy must be intended not as "liberal in its traditional conceptions, but in some new perspectives, radical and plural ${ }^{60}$, , because only in strong democracies there will be a possibility of avoiding inhumane acts as forced marriages. With the achievement of these intentions, the unity of human rights in its first meaning might be reached again, as well as the recognition of the human behind the human rights ${ }^{61}$ : the leading force of development and social inclusion. Only justice and inclusion will promote the identification of one in an-other and every human; and then, hopefully identities and dignity will be the center and the focus of social relations based in memory and hope, shared in social ambiances and with community fellows.

Lastly, it is significant to remember that the hybrid model of the Supreme Court for Sierra Leone was of a great value to permit domestic laws to be combined with international law standards; the denial of cultural procedures that encompass citizens and their aims and intentions, as well as imposition of a necessary unique framework to judge would mean that there is only one path to pursue justice. In contrary of what we suggest, it would be, however, an homogenous and totalizing violence, a way to create a constant tension between local communities and the international system of protection of human rights: and the denial of the otherness in societies is what commonly leads to conflicts, not what solve them.

\section{References}

AGAMBEN, Giorgio. Homo Sacer, o poder soberano e a vida nua. Belo Horizonte: Editora UFMG, 2010.

BARNES, Catherine; POLZER, Tara. The Sierra Leone peace process: learning from the past to address current challenges. Conciliation Resources, London, Sept. 2000.

BARRETO, Maira de Paula. Os direitos humanos e a liberdade cultural. Revista Antropos, v. 1, ano 1, nov. 2007.

60 KOZICKI, Katya. A política na perspectiva da filosofia da diferença. In: OLIVEIRA, Manfredo. et. al. (Org.). Filosofia política contemporânea. Petrópolis: Vozes, 2003. p. 141-160.

61 DOUZINAS, Costas. Quem são os 'bumanos' dos direitos?. Disponível em: <http://revolucoes.org.br/v1/>. Acesso em: 10 dez. 2014.
BLACK, Lisa. Arranged - not forced - marriages a good match in many cultures. Chicago Tribune, Chicago, 27 July 2011. Available at: <http://articles.chicagotribune.com/2011-07-27/news/ct-x-0727-arranged-marriages-20110727_1_marriages-family-traditions-stephanie-coontz>. Access in: 27 Oct. 2014.

CLARK, James M. Forced Marriage: The Evolution of a New International Criminal Norm. Aberdeen Student Law Review, Aberdeen, v. 3, p. 4-27, 2012.

DIVISION FOR THE ADVANCEMENT OF WOMEN. Expert group meeting. In: PEACE AGREEMENTS AS A MEANS FOR PROMOTING GENDER EQUALITY AND ENSURING PARTICIPATION OF WOMEN: A FRAMEWORK OF MODEL PROVISIONS. 2003, Ottawa. Aidé-Memoire. Otawa: DAW, 2003. Available at: <http://www.un.org/ womenwatch/daw/egm/peace2003/>.

DOUZINAS, Costas. Quem são os 'bumanos' dos direitos?. Disponível em: < http://revolucoes.org.br/v1/>. Acesso em: 10 dez. 2014.

GERAGHTY, Mark. The Rwandan state's campaign against genocide ideology. Available at: <http://www.mmg.mpg. $\mathrm{de} /$ research/all-projects/the-rwandan-states-campaign-against-genocide-ideology/ $>$. Acessed: 08 July 2015.

GRAMSCI, Antônio. Risorgimento: notas sobre a Itália. Tradução Luiz Sérgio Henriques. Rio de Janeiro: Civilização Brasileira, 2002.

HALL, Stuart. The problem of ideology: Marxism without guarantees. Journal of Communication Inquiry, Iowa, v. 10, n. 2, June 1986.

HAYNER, Priscila. Negotiating peace in Sierra Leone: confronting the justice challenge. Report, Geneva, Dec. 2007.

HUMAN RIGHTS WATCH. Bringing Justice: the Special Court for Sierra Leone. Available at: <https://www. hrw.org/report/2004/09/08/bringing-justice-specialcourt-sierra-leone/accomplishments-shortcomingsand >. Access in: 24 Oct. 2014.

HUMAN RIGHTS WATCH. I've never experienced happiness. Available at: <http://www.hrw.org/reports/2014/03/06/ive-never-experienced-happiness $>$. Accessed: 24 Oct. 2014. 
ICTY. 25 may 1993, art. 5(c);(g).

ICTY. Prosecutor vs. Kunarac et al. Case no IT-96-23T \& IT-96-23/1-T, 2001. Avaiable at: <http://www.icty. org/x/cases/kunarac/tjug/en/kun-tj010222e.pdf>.

JALLOH, Charles Chernor. The Sierra Leone Special Court and Its Legacy: the impact for Africa and International Criminal Law. New York: Cambridge University Press, 2014.

KERSTING, Wolfgang. Universalismo e direitos humanos. Porto Alegre: EDIPUCRS, 2003.

KOZICKI, Katya. A política na perspectiva da filosofia da diferença. In: OLIVEIRA, Manfredo. et. al. (Org.). Filosofia politica contemporânea. Petrópolis: Vozes, 2003.

LACLAU, Ernesto; MOUFFE, Chantal. Hegemonia y estrategia socialista: hacia una radicalición de la democracia. 2. ed. Buenos Aires: Fondo de Cultura Económica de Argentina, 2004.

LAFER, Celso. A reconstrução dos direitos humanos: a contribuição de Hannah Arendt. São Paulo: Companhia das Letras, 2003.

LIMA, Abili Lázaro de Castro, 2006.

MOON, Ban Ki.Transcript of the Secretary-General's remarks at Joint Press Conference with President of Sierra Leone, 2014. Avaiable at: <http://www.un.org/sg/offthecuff/index.asp?nid=3337> . Accessed in: 24 Oct. 2014.

NEVES, Marcelo. Transconstitucionalismo. São Paulo: Martins Fontes, 2009.

ROME Statute of the International Criminal Court, 2002.

SCARRY, Elaine. The Difficulty of Imagining Other Persons. In: HESSE, Carla; POST, Robert. Human rights in Political Transitions: Gettysburg to Bosnia. NewYork: Zone Books, 1999.

SCHARF, Michael P. Forward: Lessons from the Saddam Trial. Faculty Publications, Cleveland, n. 115, 2007.

SCSL. Promotor vs. Alex TambaBrima. Case N. SCSL2004-16-A. Avaiable at: <http://www.rscsl.org/Documents/Decisions/AFRC/Appeal/675/SCSL-0416-A-675.pdf>. Accessed: 15 jul. 2014.

SINGER, Peter. Crianças em armas. Colares: Pedra da Lua, 2009.

TRUTH AND RECONCILIATION COMISSION. Witness to Truth. v. 2.

UNITED NATIONS. Human Rights Council. Thematic study on the issue of violence against women and girls and disability. New York: UN, 2012.

UNITED NATIONS. Security Council. Repertoire of the Practice of the Security Council, 2004. Avaiable at: <http:/ / www.un.org/en/sc/repertoire/2004-2007/Chapter $\% 208 /$ Thematic/04-07_8_role $\% 20$ of $\% 20$ civil $\% 20$ society $\% 20$ in $\% 20$ post-conflict $\% 20$ peace-building. pdf>. Accessed: 10 Oct. 2014.

WOMEN UNDER SIEGE. Sierra Leone. Available at: $<$ http://www.womenundersiegeproject.org/conflicts/ profile/sierra-leone>. Accessed: 20 Sept. 2014.

ZIZEK, Slavoj. Bem-vindo ao deserto do real: cinco ensaios sobre o 11 de Setembro e datas relacionadas. Tradução Paulo Cezar Castanheira. São Paulo: Boitempo, 2003.

ZIZEK, Slavoj. Eu não sou um daqueles esquerdistas loucos. Folha de São Paulo, São Paulo, 29 set. 2013. Disponível em: <http://www1.folha.uol.com.br / fsp/ilustrissima /131366-quoteu-nao-sou-um-aquelesesquerdistas-loucosquot.shtml>. Acesso em: 10 out. 2013. 
Para publicar na Revista de Direito Internacional, acesse o endereço eletrônico www.rdi.uniceub.br ou www.brazilianjournal.org.

Observe as normas de publicação, para facilitar e agilizar o trabalho de edição. 